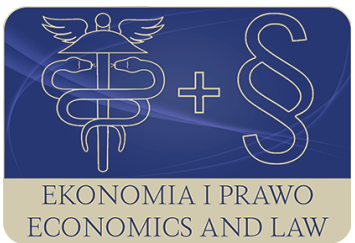

EKONOMIA I PRAWO. ECONOMICS AND LAW

Volume 18, Issue 1, March 2019

p-ISSN 1898-2255, e-ISSN 2392-1625

www.economicsandlaw.pl

BOOK REVIEW

received 17.01.2019; revised 00.00.2019; accepted 31.03.2019

Citation: Bratianu, C. (2019). Book review: Dima, A.M. (Ed.). (2018). Doing business in Europe: economic integration processes, policies, and the business environment. Ekonomia i Prawo. Economics and Law, 18(1): 111-115. doi:10.12775/EiP.2019.009.

\title{
Book review: Dima, A.M. (Ed.). (2018). Doing business in Europe: economic integration processes, policies, and the business environment
}

Cham: Springer International Publishing. ISSN 1431-1941 and 2197-716X (electronic), ISBN 978-3-319-72238-2 and 978-3-319-72239-9 (eBook). pp. 450. doi:10.1007/978-3-319-72239-9.

\section{CONSTANTIN BRATIANU}

UNESCO Department for Business Administration

Bucharest University of Economic Studies, Faculty of Business Administration, Calea Grivitei 2A, sector 1, 010731 Bucharest, Romania ๑ constantin.bratianu@gmail.com (D) orcid.org/0000-0002-1029-7384

A.M. Dima is a full professor and director of the UNESCO Department for Business Administration, Faculty of Business Administration, Bucharest University of Economic Studies. She graduated from the International Business and Economics Faculty, Bucharest University of Economic Studies, and obtained her $\mathrm{PhD}$ in international business and economics from the same university. Her academic fields of interests are international business, competition policy, European integration and higher education. She is the president of the Society for Business Excellence and Editor-in-Chief of the international journal Management \& Marketing. Challenges for the Knowledge Society (indexed in many international databases, including SCOPUS and Web of Science - Emerging Sources Citation Index). A.M. Dima published many papers in international journals, 
17 book chapters and edited the book Handbook on research on trends in European higher education convergence (2014).

As the editor of the present book, professor A.M. Dima succeeded in creating an international team of 44 experts from Austria, Estonia, France, Germany, Italy, Nigeria, Poland, Romania, Spain and USA who wrote 20 chapters on the main topics related to performing business in Europe. Considering the global business environment turbulence and the reshaping global geopolitical strategies, as well as some of the conflicting emergent strategies coming from countries like Poland and Hungary, doing business in Europe today is quite challenging. The purpose of the book is to capture this European business dynamics and to create a foresight for the immediate future. The book is a valuable resource for a large spectrum of people involved in business and geopolitical strategies from experts to researchers and students. It is one of the rare efforts to integrate such a great diversity of facts, events, and expert opinions on the European business landscape and dynamics.

European Union between the big bang and the big crunch. The authors, V.F. Alarcon, S. Hadad and S.I. Goia provide insights into the political, economical and social challenges of the European Union (EU), especially after Brexit and new political strategies adopted by Poland and Hungary. The chapter analyzes the phenomena that lead to the current situation in the EU by shading light on the multi-layered causes and consequences of UK leaving the EU. Also, there are reflections on the conflicts between different national and international political and economical entities with many consequences on the sustainability of EU.

The single European market: challenges for doing business. Professor D. Miron provides some reflections on the real meaning of economic integration, after the political one of the member states. The chapter analyses the single internal market as an essential stage of the European integration process stressing the four freedoms of goods, services, capitals and human resources. This topic is well-integrated with that of the next chapter of the book European Union trade policy, written by professor D. Miron. The main idea of this chapter is to discuss the rationales for a single community trade policy. The author remarks that the present state of business affaires is marked by tensions between multilateralism and regionalism, which raises numerous challenges to the resilience of the global trading system. Finally, the author would like to clarify the contribution of trade policy to implementing Europe 2020 Strategy goals.

European cohesion policy. The authors, G.C. Pascariu and C. Incaltarau consider that the European cohesion policy is the largest and most complex policy of the EU. The main goal of this powerful policy is to reduce the gaps between the developed and the emergent economies, which creates many frictions and inertial forces in accelerating the development of the whole European region. The authors discuss the theoretical issues related to public interventions on cohesion in the process of European integration, and they explain the system of cohesion policy coordination, regulation and implementation. 
The relationship between competition policy and innovation in the European business environment. The authors, A.M. Dima, R. Cantaragiu, and L.G. Istudor from Bucharest University of Economic Studies, built up their analysis on the idea that competition is an essential driving force in the functioning efficiently any market. Competition policies and strategies provide the necessary instruments for encouraging and improving the competitive process. These purposes are achieved in the business environment through completion laws and enforced by competition authorities. Companies should be stimulated to innovate but only within the given legislation framework.

The Euro and the European monetary policy: a critical view. Professor C. Paun analyzes the European monetary policy and the role played by the euro in achieving a single market, before and after the enlargement of the EU. The evolution of euro zone after the introduction of a single currency was not merely positive. The evolution reached a bifurcation trajectory after the enlargement of the EU with Eastern European Countries (EEC), i.e. an EU with different economic speeds and different economic powers on the same single market.

Fiscal policy of the EU: implications for Romania. Professors I. Dumitru and I. Dumitru focus their analysis on the fiscal European policy and the resulting consequences on the Romanian economy. The chapter discusses the evolution of the EU economic governance regulation, starting with the Maastricht Treaty from 1992, focusing on the more recent regulations outlined in the Treaty on Stability, Coordination and Governance. The pressure put on the Romanian economy can be reduced by accelerating the absorption of EU funds and the increase in public spending efficiency.

The European Energy Union (EEU): from dream to reality. The authors, A. Tantau, H. Berg, and M.A. Maasen focus their analysis on the energy issues of the EU. The authors underline the fact that renewable energy resources should play an increasing role in the immediate future in concordance with the policies and strategies made for decreasing the environmental pollution. Also, they discuss the new EU strategies 2020, 2030, and 2050.

EU policy for digital society. The authors, T. Burger-Helmchen and G.-M. Meghisan-Toma present in this chapter the emergent issues of the knowledge economy, especially the process of business digitalization and its consequences for the society. The chapter focuses on the main stages towards a digital society at the level of the EU's countries. Also, the authors discuss the importance of the new legislation framework for a digital market and a digital society.

Social entrepreneurship across the European Union: an introduction. The authors, C. Volkmann, S.I. Goia, and S. Hadad present in this chapter the evolving phenomenon of social entrepreneurship and consider it as an indispensable part of the economy and it is now regarded as the driving engine of the social economy. Also, they present some insights into the scale and legislative, social and economic framework regarding social entrepreneurship at the level of EU.

The role of social enterprises at European level. The authors, C. Paunescu and R. Evans remark that social enterprise model of business is gaining more and more 
in popularity since it provides opportunities to combine societal goals with commercial objectives for the benefit of both community and environment. They discuss about the specific forms of organization of social enterprise and the common fields where they operate with associated target groups. The authors provide also some case studies on social enterprises.

Entrepreneurship of family businesses in the European Union. The authors, L. Sulkowski, A. Marjanski, and J. Sulkowska focus on the small business landscape done at the family levels. Family entrepreneurship as a form of economic activity plays a significant role in enlargement processes, integration and competitiveness improvement policies of the EU. The authors explain the unique values that families businesses bring to the economy and society of EU countries.

The effects of European integration in the tourism industry: consequences of the last accession waves. The authors, L. Nicolescu and M.-I. Ana focus their analysis on the tourism industry, which created new opportunities with the last accession waves in the EU. The chapter discusses the main EU policies in the tourism industry, both for the Western and Eastern countries. Statistics show a great advantage for the Western countries, but the new member states try to develop their own strategies to develop much more the tourism industry. The authors provide also as a case study the situation of Romania in the last years.

Sociotechnical challenges of transition economy SMEs during EU integration. The authors, N.R. Vajjhala and K.D. Strang focus their analysis on the SMEs in the emergent economies and on the sociotechnical challenges they face due to global competition. The chapter is based on a qualitative and quantitative research performed in Albania, as a typical emergent economy in Europe. Their findings show that investment in new technologies constitutes an integral part of the growth and development of SMEs, and their emergent economies.

From successful SMEs to entrepreneurial society and the importance of the entrepreneurial mindset. Professors L. Rasca, A. Deaconu and S. True focus in this chapter on the importance of entrepreneurial thinking and the driving force of motivation in initiating and developing business. As they emphasize, the entrepreneurial society represents the hope of moving economy from stagnation to prosperity. The chapter aims to explain what such a society is, why it is so important to mankind, and how it can be created.

The creative economy in Romania, a key factor of economic integration in the European Union. The authors, S.-G. Toma, D. Peptenatu, I. Andronache, H. Ahammer, R.-D. Pintilii, C.-C. Draghici, and A.G. Simion analyze the creative component of the Romanian economy and show its importance in the economic integration process. As the author emphasize, the creative economies have proved to be a veritable development vector, showing superior capacity for adapting to structural crises, and contributeing to the economic integration of Romania in the EU.

Differentiation strategy and rankings in higher education: role of rankings in building a strategy. Professor M. Iordache-Platis presents in this chapter the competition phenomenon existing in the higher education not only at the EU level but 
at the global level. The ranking methodologies, especially the Academic Ranking of the World Universities (ARWU) much better known as the Shanghai ranking, created a new dynamics between the universities on the global market and put a lot of pressure on the universities from emergent economies like Romania to improve their level of visibility and competitiveness.

Big business bias? European policy at the expense of small and alternative ventures. The authors, V. Rundshagen and M. Raueiser offer a critical perspective on EU policy and the challenges it imposes on SMEs in general and alternative businesses in particular. The focus is on the domains of banking and agriculture. The chapter shows the major dilemmas of EU policy for small and alternative banks, as well as for small and alternative farms.

Innovation support strategies for enhancing business competitiveness in the European Union: programmes, objectives and economic impact assessment. Professors F. Bellini and F. D'Ascenzo focus their analysis on the research, development and innovation programmes of the EU, which play an important role in reshaping the development of the old continent. The aim of this chapter is to discuss the policy that drives these programmes and to give some insights on how they are assessed in order to measure their impact.

Information and communication technologies (ICTs) in enterprises on the over the counter (OTC) markets in European Union: case study of Polish new connect market. The authors, J. Wozniak and W. Wereda focus their analysis on the Polish market, with the central attention on the information and communication technologies role in supporting the economic development.

On the whole, the present book edited by professor A.M. Dima is an excellent integration of the issues and new trends in the European business. It is a valuable information and reflective resource for all the people involved in business, as well as researchers and students.

\section{References}

Dima, A.M. (Ed.). (2014). Handbook on research on trends in European higher education convergence. Hershey: IGI Global. doi:10.4018/978-1-4666-5998-8.

\section{Notes}

Author contributions: author has given an approval to the final version of the article. 
